\title{
ANALISIS JENIS USAHA DAN LABA ATAS BIAYA PADA PEDAGANG DI KABUPATEN MANOKWARI
}

\author{
Sarah Usman 1 \\ Fakultas Ekonomi dan Bisnis, Universitas Papua, Manokwari
}

\begin{abstract}
\begin{tabular}{l|l} 
Abstrak & Penelitian ini bertujuan untuk menganalisis potensi pertumbuhan ekonomi pedagang
\end{tabular} lokal di Kabupaten Manokwari, Papua Barat berdasarkan jenis produk dan penerimaan atas biaya. Penelitian ini menggunakan pendekatan deskriptif kuantitatif. Sampel penelitian terdiri dari 74 responden yang diambil secara acak (simple random sampling) di 2 pasar tradisional yaitu Pasar Sanggeng dan Pasar Wosi. Data penelitian diolah menggunakan SPSS dengan metode statistik deskriptif-frekuensi. Hasil penelitian menunjukkan bahwa produk yang paling banyak diperdagangkan adalah umbi-umbian dan buah-buahan sebesar $28,4 \%$ diikuti oleh produk laut/ternak dan pedagang campur $24,3 \%$, dan produk sayur mayur $23 \%$. Rasio penerimaan terhadap biaya yang dikeluarkan minimal adalah 0,9 , dengan nilai yang tertinggi 60,00 dan rata-rata 7,52. Rasio penerimaan terhadap biaya yang dikeluarkan rata-rata sebesar 7,52 kali yang berarti bahwa pedagang di tanah Papua seharusnya memiliki tingkat kesejahteraan yang baik dan potensi usaha lokal bisa lebih maju lagi. Peningkatan kesejahteraan pedagang tentunya akan meningkatkan pertumbuhan ekonomi lokal. Namun, masih banyak pedagang yang hasil usahanya hanya cukup untuk sekedar memenuhi kebutuhan seharihari. Oleh karena itu, perlu adanya peningkatan pengetahuan dan pembimbingan usaha bagi pedagang di tanah Papua.
\end{abstract}

Kata Kunci : $\quad$ biaya, pasar, pedagang, penerimaan, produk

\begin{abstract}
The objective of this research is to analyze the potential of local traders' economic growth in Manokwari Regency, West Papua based on the type of product sold and the profit to cost ratio. This research uses a quantitative descriptive approach. The research sample consisted of 74 respondents taken randomly using a simple random sampling method at the traditional markets of Sanggeng Market and West Market. Data were processed using SPSS with descriptive statistical methods-frequency. Results showed that the most products sold in traditional markets in Manokwari Regency were tubers and fruits by $28.4 \%$, followed by sea/livestock products and mixed products by $24.3 \%$, and vegetables by $23 \%$. The lowest profit to cost ratio was 0.9 and the highest was 60 . The average profit to cost ratio was 7.52 which means that traders in Papua should have been at a better welfare level. Likewise, local businesses should have been grown better. Increasing local trader welfare is also increasing the level of local economic growth. However, many traders can only earn income to fulfill their daily needs. Therefore, they should improve their business skills and knowledge by following some business training and assistance programs.
\end{abstract}

Keywords : cost, market, product, profit, traders

Fakultas Ekonomi dan Bisnis

Universitas Papua

E-mail: s.usman@unipa.ac.id 


\section{Pendahuluan}

Kabupaten Manokwari terletak pada posisi di bawah garis katulistiwa, antara $0^{\circ} 14^{\prime} \mathrm{s}$ dan $130^{\circ} \quad 31^{\prime}$ e. Luas Wilayah Kabupaten Manokwari mulanya 4.650,32 km2 namun karena ada perpindahan beberapa kampung dari wilayah lain, maka luas wilayahnya menjadi $4.863,40 \mathrm{~km} 2$ yang digunakan untuk perhitungan kepadatan penduduk real dan terbagi menjadi sembilan distrik. Namun, terdapat perubahan administratif yaitu pindahnya 13 kampung yang dahulunya di Kabupaten Pegunungan Arfak kini menjadi bagian dari Distrik Warmare, Kabupaten Manokwari sehingga luas wilayah menjadi $4.863,40 \mathrm{~km} 2$ (BPS, 2017).

Berdagang merupakan jenis pekerjaan yang mayoritas dilakukan oleh masyarakat lokal di indonesia termasuk di Manokwari Provinsi Papua Barat. Menurut data BPS (2017) pada tahun 2016, Pedagang di Kabupaten Manokwari didominasi oleh pedagang kecil dengan 382 orang, diikuti pedagang menengah 299 orang dan hanya 16 orang yang merupakan pedagang besar.

Kegiatan pertanian pada masyarakat kabupaten Manokwari merupakan kegiatan yang bersifat hilir. Selanjutnya hasil pertanian ytersebut dijual sendiri pada pasar atau tengkulak yang datang langsung pada masyarakat yang menjadikan sektor pertanian dan perdagangan menjadi sektor lunci perekonomian di Manokwari (Sagrim, dkk, 2017). Masyarakat mayoritas melakukan usaha berdagang dengan produk hasil alam daerah, yaitu seperti hasil perkebunan dan pertanian yang ditanam sendiri ataupun di beli dari pihak lain sebelum dijual lagi. Masyarakat melakukan usaha berdagang terlihat setiap hari dan dengan durasi waktu sampai produk habis terjual. Jenis pedagang merupakan perseorangan atau para pedagang menjalankan sendiri usaha berdagang yang dilakukan. Hal ini mayoritas dilakukan. Banyaknya Pedagang Menurut Jenis Perdagangan dan Distrik di Kabupaten Manokwari Tahun 2014 - 2016 terlihat pada tabel berikut:

\section{Tabel 1. Banyaknya Pedagang Menurut Jenis Perdagangan}

\begin{tabular}{lccc}
\hline \multicolumn{1}{c}{ Distrik } & $\begin{array}{c}\text { Pedagang } \\
\text { Besar }\end{array}$ & $\begin{array}{c}\text { Pedagang } \\
\text { Menengah }\end{array}$ & $\begin{array}{c}\text { Pedagang } \\
\text { Kecil }\end{array}$ \\
\hline Warmare & - & - & 16 \\
Prafi & - & 7 & 19 \\
Manokwari & 14 & 235 & 264 \\
Barat & & 9 & 16 \\
Manokwari & - & 1 & 4 \\
Timur & & 35 & 27 \\
Manokwari & - & 2 & - \\
Utara & & 7 & 26 \\
Manokwari & - & 3 & 10 \\
Selatan & 2 & 299 & 382 \\
Tanah Rubu & - & 187 & 461 \\
Masni & - & 228 & 534 \\
Sidey & 16 & & \\
\hline Jumlah 2016 & 19 & & \\
Jumlah 2015 & 0 & & \\
Jumlah 2014 & 017 & & \\
\hline
\end{tabular}

Sumber: DDA, 2017

Berdasarkan hasil perhitungan PDRB menurut lapangan usaha atas dasar harga berlaku Kabupaten Manokwari tahun 2016, lima kategori penyumbang terbesar PDRB Kabupaten Manokwari adalah kategori konstruksi (25,00\%), kategori administrasi pemerintahan, pertahanan dan jaminan sosial $(18,55 \%)$, pertanian $(12,95 \%)$, perdagangan dan reparasi $(12,01 \%)$, serta transportasi dan pergudangan (5,68\%). Dimana pertanian berada di urutan ketiga dalam memberikan sumbangsih kepada daerah. Sumbangsih yang berasal dari sektor pertanian sejalan dengan jumlah pedagang dengan skala kecil yang memiliki urutan pertama di Kabupaten Manokwari. Ketika pendapatan kepada daerah masuk urutan ketiga terbesar, maka pendapatan per orang pedagangpun harusnya besar. Namun untuk memastikan hipotesis awal tersebut maka perlu dilakukan penelitian tentang jenis produk yang diperdagangkan, besarnya pendapatan dan bagaimana tingkat rentabilitas yang diperoleh bagi pedagang lokal di pasar tradisional kabupaten Manokwari.

Penelitian sebelumnya pernah dilakukan berkaitan pendapatan (Usman, 2017) berkaitan dengan analisis manfaat uang bagi pedagang lokal pasar tradisional di Kabupaten Manokwari Provinsi Papua Barat dimana pendapatan pedagang rata-rata sebesar sebesar Pendapatan pedagang lokal yaitu 
Rp.10.000.000 - Rp. 20.000.000 setiap bulan Pemanfaatan uang sebesar $51 \%$ yaitu investasi $25,8 \%$, konsumsi 19,3\% dan berjaga-jaga 5,8\%. Namun dengan jumlah sample yang lebih sedikit dan sample tidak dikelompokkan berdasarkan jenis produk, sehingga masih perlu dilakukan penelitian dengan menggolongkan berdasarkan jenis produk.

\section{Metodologi}

Penelitian ini menggunakan pendekatan deskriptif kuantitatif, dimana dalam menjawab rumusan masalah dijelaskan secara deksriptif melalui data kuantitatif (Sugiyono, 2014). Variabel yang di teliti adalah jenis produk, pendapatan dan rasio laba atas biaya. Analisis dilakukan dengan menggunakan SPSS yaitu metode statistik deskriptif yaitu frekwensi untuk melihat persen dari jenis produk yang diperdagangkan dan statistik deskriptif untuk melihat minimal, maksimal dan rata-rata berdasarkan hasil analisis keuangan yaitu rasio profit per cost (laba per biaya).

Populasi dalam penelitian ini adalah keseluruhan pedagang lokal di dua pasar tradisional yaitu pasar Sanggeng dan Wosi di Kabupaten Manokwari Provinsi Papua Barat. Sampel sebanyak 74 orang, dengan pengambilan sampel secara acak (simple random sampling) dengan instrumen penelitian yaitu angket daftar pertanyaan yang telah disusun oleh peneliti.

Analisis dilakukan dengan menggunakan SPSS yaitu metode statistik deskriptif dengan melihat distrubusi frekwensi untuk mengidentifikasi prosentase dari jenis produk yang diperdagangkan dan statistik deskriptif untuk melihat minimal, maksimal dan rata-rata dari hasil analisis keuangan yaitu rasio revenue per cost. Revenue per cost ratio (R/C ratio) adalah perbandingan antara penerimaan total dengan biaya total atu disebut juga $\mathrm{R} / \mathrm{C}$ ratio atas biaya total (Asmarantaka, 2013). Menurut Soekartawi (2006) dalam Yunita (2013) bahwa Revenue/Cost Ratio adalah merupakan perbandingan antara total pendapatan dengan total biaya.

$\mathrm{R} / \mathrm{C}$ ratio atas biaya total dihitung dengan persamaan:
$\mathrm{R} / \mathrm{C}=$ Total Penerimaan $/$ Total Biaya

Keterangan:

Jika R/C >1 maka usaha untung/layak

Jika $\mathrm{R} / \mathrm{C}<1$ maka usaha rugi/tidak layak

\section{Hasil dan Pembahasan}

\section{Jenis Produk}

Penelitian yang dilakukan bagi pedagang lokal di pasar tradisional Manokwari, dengan karakteristik jenis produk yang diperdagangkan adalah seperti gambar 1 dibawah ini:
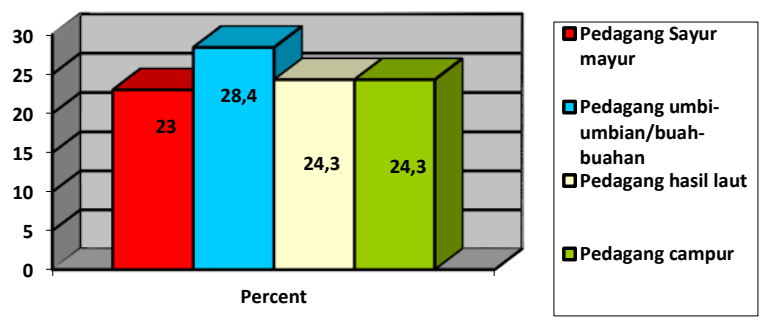

\section{Gambar 1. Jenis Usaha per Jenis Produk}

Salah satu keunggulan Manokwari dalam perdagangan adalah bahan baku yang mudah dicari dan banyak tersedia di masyarakat (Toyib, dkk. 2018). Jenis produk yang diperdagangkan pedagang tertinggi adalah umbi-umbian dan buah-buahan sebesar 28,4\%. Hal ini terkait potensi alam dimana umbiumbian sangat mudah ditanam dan dijual. Begitupun dengan buah-buahan, Manokwari merupakan kota di Papua yang memiliki potensi hasil buah-buahan yang banyak. Walaupun sesuai musim namun, untuk buah pisang setiap saat tersedia dan diperdagangkan. Terendah sebesar 23\% adalah sayur mayur, hal ini disebabkan pedagang lokal yang khusus menjual sayur tanpa mencampur dengan produk lain tergolong sedikit. Umumnya pedagang mencampur jenis produk sayur dengan produk lainnya. Sehingga hasil penelitian menggolongkan pedagang sayur dengan frekuensi terkecil, dibandingkan jenis produk lainnya. 


\section{Laba Usaha Pedagang}

Laba diperoleh dari selisih pendapatan dan biaya. Pendapatan merupakan hasil dari usaha berdagang, dimana pendapatan bersifat fluktuatif atau berubah-ubah. Dari hasil penelitian diperoleh hasil besarnya pendapatan pedagang lokal pasar tradisonal adalah seperti tabel 2 dibawah ini:

\section{Tabel 2. Hasil Tes Statistik Deskriptif Pendapatan Pedagang}

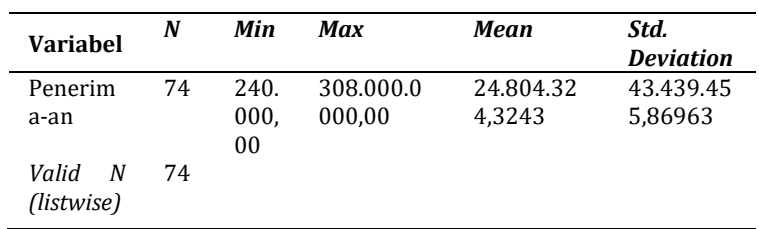

Sumber: Data diolah, 2018

Berdasarkan tabel diatas terlihat bahwa minimal penghasilan pedagang lokal sebanyak Rp. 240.000 per bulan dan tertinggi sebesar Rp.308.000.000 per bulan dengan rata-rata Rp.24.804.300 per bulan per pedagang. Jika di convert per harinya terendah sebesar Rp. 9.231, tertinggi sebesar Rp.11.846.154 dan rata-rata sebesar Rp. 954.012. berdaasrkan sample pedagang dengan penghasilan Rp.240.000 sejumlah 1 orang dan dengan penjualan yang tidak setiap hari. Pendapatan tertinggi di peroleh sebanyak 1 orang dengan jenis usaha adalah campur dan penjualan skala besar. Sedangkan rata-rata penjualan merupakan pendapatan pada umumnya dari setiap pedagang lokal pasar tradisional di Manokwari, dengan durasi waktu yang dilakukan adalah 26 hari dalam sebulan yaitu senin-sabtu. Karena minggu adalah hari ibadah bagi sebagian besar pedagang. Adapun pengeluaran yang dilakukan pedagang, seperti Tabel 3 berikut:

\section{Tabel 3. Hasil Tes Statistik Deskriptif Pengeluaran Pedagang}

\begin{tabular}{lcrrr}
\hline & N & $\begin{array}{c}\text { Minimu } \\
\boldsymbol{m}\end{array}$ & Maximum & Mean \\
\hline Pengeluara & 7 & $100.000,0$ & $84.312 .000,0$ & $8.442 .635,130$ \\
$\mathrm{n}$ & 4 & 0 & 0 & 0 \\
Valid $N$ & 7 & & & \\
(listwise) & 4 & & & \\
\hline
\end{tabular}

Sumber: Data diolah, 2018
Berdasarkan data terlihat pada tabel 3 diatas bahwa minimal pengeluaran pedagang sebesar 1.000.000, tertinggi Rp.84.312.000 dan ratarata sebesar Rp. 8.442.635.

Hasil pendapatan dan pengeluaran dari 2 tabel diatas maka di peroleh besarnta laba usaha pedagang. Laba diperoleh dari hasil berdagang dikurangi pengeluaran yang dikeluarkan setiap bulan. Terlihat pada Tabel 4 dibawah ini:

\section{Tabel 4. Hasil Tes Statistik Deskriptif Deskriptif Laba Pedagang}

\begin{tabular}{lccrr}
\hline & N & $\begin{array}{c}\text { Minimu } \\
\boldsymbol{m}\end{array}$ & Maximum & \multicolumn{1}{c}{ Mean } \\
\hline Laba & 7 & 0,00 & $301.380 .000,0$ & $18.491 .851,351$ \\
& 4 & & 0 & 4 \\
Valid $N$ & 7 & & & \\
(listwise & 4 & & & \\
) & & & & \\
\hline
\end{tabular}

Sumber: Data diolah, 2018

Hasil laba berdasarkan tabel 4 diatas bahwa laba atau profit minimal dibawah dari $0 \%$ atau minus (rugi), tertinggi sebesar Rp. 301.380 .000 dengan rata-rata Laba sebesar Rp, 18.491.851 per pedagang setiap bulan.

\section{$\underline{\text { Rasio Penerimaan atas Biaya }}$}

Rasio Penerimaan atas biaya (R/C) diperoleh dari jumlah pendapatan dibagi dengan jumlah pengeluaran. Dalam penelitian dilakukan dengan menjumlahkan pendapatan dan pengeluaran, kemudian di bagi berdasarkan pendapatan dan pengeluaran setiap bulan. Adapun hasil yang diperoleh seperti Tabel 5 berikut:

\section{Tabel 5. Hasil Tes Statistik Deskriptif Laba} atas Biaya Rasio

\begin{tabular}{lcccc}
\hline & N & Min. & Max. & Mean \\
\hline Revenue_Cost & 74 &, 09 & 60,00 & 7,5235 \\
Valid N (listwise) & 74 & & & \\
\hline
\end{tabular}

Sumber: Data diolah, 2018

Berdasarkan Tabel 5 diatas bahwa rasio penerimaan terhadap biaya yang dikeluarkan minimal diperoleh pedagang adalah 0,9 dan tertinggi sebesar 60,00 dengan rata-rata sebesar 7,52. Artinya terlihat bahwa secara rata-rata penerimaan yang diterima oleh 
pedagang lokal dibandingkan dengan pengeluaran adalah sebesar 7,52 kali dari total biaya yang dikeluarkan. Dengan nilai tersebut maka berdagang memberikan keuntungan yang besar bagi pedagang. Menurut (Asmarantaka, 2013) batas rasio penerimaan atas biaya dikatakan baik jika nilai rasio diatas 1. Sehingga potensi keuntungan berdagang di pasar tradisonal melebihi standar penilaian. Jenis produk yang diperdagangkan berbeda antara pedagang lokal asli Papua dan non asli Papua. Bagi pedagang lokal asli Papua Pemilihan jenis produk yang diperdagangkan disesuaikan dengan hasil kebun yang dimiliki. Sehingga jenis produk bisa sama namun dengan produk yang berbeda-beda. Seperti sayur mayur, pedagang di Manokwari menjual dengan berganti-gantian sesuai hasil panen yang diperoleh dari kebun milik sendiri. Sehingga terlihat bahwa alasan berdagang disesuikan dengan hasil kebun. Namun bagi non-asli Papua produk yang di perdagangkan disesuikan dengan kebutuhan konsumen dan ketersediaan produk, karena bagi pedagang non-asli Papua produk dibeli kepada petani atau pemasok dan kemudian di jual kembali. Alasan berdagang lebih kepada mencari peluang bisnis yang baik dan menguntungkan (Kasikoen dan Baw, 2014).

Alasan pemilihan jenis produk dalam melakukan usaha berdagang berbeda antara pedagang non asli Papua dan asli Papua. Bagi pedagang asli Papua juga terbagi dua yaitu antara masyarakat pantai dan gunung. hal ini sesuai penelitian sebelumnya (Naftali, dkk : 2016) bahwa masyarakat pantai dan daerah pengunungan terdapat perbedaan niat yang mempengaruhi dalam melakukan kegiatan berwirausaha daerah pegunungan lebih tinggi dipengaruhi oleh empat faktor. Dimana, niat wirausaha lebih tinggi dipengaruhi dikarenakan faktor achievement (keinginan berprestasi), Independent (kemandirian), risk (pengambilan risiko) dan inovasi. Sedangkan daerah pantai faktor yang lebih tinggi mempengaruhi adalah Locus of control (keinginan dalam diri) dan self efficacy (keyakinan akan kemampuan diri).

Artinya bahwa dalam memilih produk usaha masyarakat asli Papua lebih memilih produk hasil kebun karena secara budaya, mereka telah mengenal cara berkebun dan memiliki pengalaman berkebin sejak masih kanakkanak. Berkebun secara turun temurun dipelajari dan menjadi budaya. Sehingga masyarakat asli dalam memilih jenis produk yang akan dijual, lebih memilih produk yang mereka kenal yaitu produk hasil berkebun. Hasil berkebunpun antar pedagang asli Papua adalah kelompok yang homogen. Rata-rata menjual umbi-umbian dan sayuran (kangkung, kacang panjang dan daun singkong). Ada beberapa yang berbeda namun sifatnya sebagai pelengkap.

Sedangkan untuk pedagang non-asli Papua dalam memilih produk lebih membaca peluang bisnis. mereka mencari produk yang dibutuhkan dan sedikit ditawarkan. Walaupun harus dibeli dari orang lain atau tempat lain, mereka akan lakukan. Karena secara peluang, mereka telah memperhitungkan dan membaca pasar. Misalnya banyak pedagang asal sulawesi menjual buah pisang berbagai jenis, dengan mengambil dari petani kebun yang berbedabeda. Ada juga yang menjual pinang kering yang diambil dari makassar. Hal ini karena pedagang non asli Papua melihat kebutuhan pisang yang dijual sebagai bahan makanan sangat banyak di Manokwari, sehingga ketersediaan buah pisang harus tercukupi. Begitupun dengan pinang kering, pedagang mengambil dari makassar karena di Manokwari sendiri tidak ada yang memproduksi pinang kering. Namun yang mengkonsumsi banyak.

\section{Analisis Laba atas Biaya Usaha Berdagang}

Winardi (2002) menyatakan bahwa pendapatan adalah semua penghasilan yang diperoleh dari pihak lain sebagai tanda balas jasa yang diberikan dimana penghasilan tersebut digunakan untuk memenuhi kebutuhan keluarga atau perseorangan. Pendapatan merupakan suatu tujuan utama dari perusahaan karena dengan adanya pendapatan maka operasional perusahaan kedepan akan berjalan dengan baik atau dengan kata lain bahwa pendapatan merupakan suatu alat untuk kelangsungan hidup perusahaan. Winardi juga mengemukakan pengertian pendapatan adalah sebagai saluran penerimaan baik berupa uang maupun barang baik dari pihak lain maupun dari hasil sendiri yang dimulai dengan 
sejumlah uang atau jasa atas dasar harga yang berlaku pada saat itu.

Pendapatan yang diperoleh pedagang lokal dalam penelitian ini relatif besar secara ratarata Rp. Rp. 24.804.324,32. namun jika dilihat berdasarkan pendapatan tertinggi dan terendah memiliki disparitas yang cukup besar yaitu Rp.240.000 - Rp. 300.800.000. artinya dalam melakukan usaha berdagang secara umum memiliki perbedaan yang tinggi. Secara umum beradasarkan informasi tambahan hal ini disebabkan oleh jenis produk yang diperdagangkan oleh beberapa pedagang adalah sama. Hal ini sejalan dengan penelitian Jaya,dkk (2014) bahwa jenis barang yang diperdagangkan akan ikut mempengaruhi pendapatan. Secara umum, hasil penelitian tersebut menemukan bahwa jenis barang dagangan yang mereka jual relatif sama antara pedagang yang satu dengan pedagang yang lainnya, seperti pedagang canang dan banten. Jadi konsumen akan menilai kualitas barang dagangan yang akan mereka beli dan tidak lupa memandang kebersihan dari barang dagangan yang pedagang jual. Dengan banyaknya konsumen yang membeli barang dagangan mereka, maka pendapatan pedagang tentunya akan semakin besar daripada pendapatan yang diterima oleh pedagang yang jarang di kunjungi oleh konsumen.

Pendapatan di pengaruhi oleh Jenis produk yang diperdagangkan sama, hal lain yaitu frekuensi menjual yang berbeda-beda. Dimana sebagian pedagang berdagang selama 7 hari dari pagi sampai malam, namun sebagian berdagang selama 6 hari bahkan ada yang 4 hari dalam seminggu. Serta dengan durasi waktu yang berbeda-beda.

Usaha berdagang memberikan pemasukan (laba) yang besar bagi pedagang lokal pasar tradisional di kabupaten Manokwari yaitu $65,2 \%$. Hal ini dikarenakan biaya yang dikeluarkan sedikit. Hasil ini berkaitan dengan produk yang di perdagangkan. Dimana, untuk produk sayur mayur, umbi-umbian/buahbuahan dan hasil laut pedagang tidak memerlukan pembiayaan yang besar. Misalnya untuk sayur mayur dan umbi-umbian/buahbuahan, secara umum berasal dari hasil kebun milik sendiri. Dimana pedagang melakukan proses mulai dari produksi sampai memasarkan, atau kata lain bahwa pedagang menanam sendiri produk, dan menjual langsung ke pasar.

Sedangkan hasil laut di peroleh dengan membeli dari nelayan, namun selain harga lebih murah dibandingkan harga jual. Para pedagang hasil laut memiliki teknik menjual dengan saling membantu menjual produk pedagang lain, jika produk yang dijual telah habis. Sehingga pendapatan tidak berasal dari hasil jualan sendiri, namun dari hasil jualan pedagang lainnya.

Hasil secara umum dari tingkat rasio penerimaan atas biaya menggambarkan bahwa usaha berdagang di pasar tradisional untuk jenis produk umbi-umbian/buah, hasil laut, produk campur dan sayur mayur memberikan potensi penghasilan yang besar bagi pedagang. Artinya secara keuntungan, pedagang di Papua atau Manokwari tepatnya memiliki pendapatan laba yang tinggi. Secara kebutuhan harusnya tercukupi, ditabung dan bisa meningkatkan kesejahteraan pedagang. Namun, pada penelitian (Usman, 2017) pedagang yang memiliki tabungan adalah dibawah 5\%. Artinya keuntungan pedagang yang tinggi digunakan secara langsung dan habis digunakan untuk berbagai kebutuhan. Sehingga banyak pedagang yang merasa hidupnya kekurangan, walaupun berdagang hasil kebun sendiri.

Pedagang merasa bahwa berdagang adalah untuk memenuhi kebutuhan hidup dan tidak fokus pada pengembangan bisnis. padahal secara keuntungan, peluang bisnis di Papua barat adalah besar dan berdasarkan hasil penelitian pedagang memiliki keuntungan 7,52 kali dari biaya yang dikeluarkan. Biaya yang dikeluarkan relatif kecil karena banyak pedagang menjual produk hasil kebun sendiri, mereka dipasar kadang tidak makan sehingga biaya yang dikeluarkan kecil, jenis produk yang diperdagangkan berbeda namun tetap hasil kebun sendiri. Berkebun diPapua tidak membutuhkan banyak biaya, karena tanah yang subur tanpa bahan kimia dan perawatan seadanya tanpa biaya tambahan. 


\section{Kesimpulan}

Jenis produk yang diperdagangkan pedagang tertinggi adalah umbi-umbian dan buahbuahan sebesar $28,4 \%$. Terendah sebesar $23 \%$ adalah sayur mayur. Dan usaha jensi produk laut/ternak dan pedagang campur sebesar $24,3 \%$ dari total 74 pedagang. Rasio laba terhadap biaya yang dikeluarkan minimal diperoleh pedagang adalah $-0,91$, tertinggi sebesar 59,00 dan rata-rata sebesar 6,52. Terlihat bahwa secara rata-rata laba yang diterima oleh pedagang lokal dibandingkan dengan pengeluaran adalah sebesar $65,2 \%$ dari total biaya yang dikeluarkan.

\section{Saran}

Penelitian ini memfokuskan kepada pedagang dengan menggolongkan responden berdasarkan lokasi pasar dan jenis produk. Namun, dalam pembahasan belum memisahkan berdasarkan pasar dan jenis produk dikarenakan jumlah data relatif kecil. Untuk itu diharapkan ada penelitian selanjutnya yang bisa mengambil penelitian dengan memfokuskan pada penggolongan berdasarkan jenis produk, namun dengan jumlah sample yang besar sehingga bisa membahas dengan memisahkan berdasarkan jenis produk. Agar diketahui jumlah pendapatan dan penerimaan atas biaya per penggolongan jenis produk yang diperdagangkan dan memisahkan antara pedagang musiman dan tetap.

\section{Daftar Referensi}

Asmarantaka, Aris. 2013. Analisis Finansial Dan Strategi Pengembangan Usaha Bandrek Lampung Pada Unit Usaha Thp Herbalist. $e$ skripsi. Fakultas Pertanian, Universitas Lampung. digital repository UNILA. website : http://digilib.unila.ac.id/1175/. diakses 20 September 2018.

BPS, 2017. Daerah Manokwari Dalam Angka, Kabupaten Manokwari, Papua Barat.
Firdausa, Rosetyadi Artistyan. 2012. Pengaruh Modal Awal, lama Usaha Dan Jam Kerja Terhadap Pendapatan Pedagang Kios Di Pasar Bintoro Demak. Skripsi. Fakultas Ekonomi Dan Bisnis Universitas Diponegoro. Semarang.

Jaya, I Putu Rian Kusuma. 2014. Analisis Pendapatan Pedagang (Studi Pada Pasar Anyar Di Kelurahan Banjar Tengah. e-journal UNDISHA.

Kasikoen, Ken Martina dan Baw, Tur Sofia Benazer. 2014. Evaluasi Kondisi Transportasi sebagai Pendukung Kegiatan Ekonomi di Kabupaten Manokwari. Jurnal Planesa. Vol 5. (20): 53-61.

Naftali, Sarah, 2016. Analisis Faktor-Faktor Yang Mempengaruhi Niat Orang Asli Papua Untuk Berwirausaha. proceeding. 1st National Conference on Business and Entrepreneurship. Universitas Ciputra, Surabaya.

Sagrim, Meky, Agus Irianto Sumule, Deny Anjelus Iyai, Michael Barasano. 2017. Potensi Unggulan Komoditas Pertanian pada Daerah Dataran Tinggi Kabupaten Pegunungan Arfak, Papua Barat. Jurnal Ilmu Pertanian Indonesia (JIPI). Vol. 22(3): 141-146.

Sugiyono. 2014. Metode Penelitian pendidikan, Bandung: Alfabeta.

Toyib, Jein Sriana, Anik Wuriasih, dan Ted Matheus Suruan. 2018. Strategi Pengembangan Usaha Kecil dan Menengah Di Kabupaten Manokwari. Jurnal Magister Manajemen (JMM) Unram. Vol 7 Nomor 4. Pp101-112.

Usman, Sarah., Suwardadi, Dirarini., dan Awom, Sarce, B. 2017. Analisis Manfaat Uang bagi Pedagang Lokal Pasar Tradisional di Kabupaten Manokwari Provinsi Papua Barat. Proceeding: 151-160. Seminar Nasional Manajemen Ekonomi Akuntansi (SENMEA) 2017- Universitas Nusantara PGRI Kediri

Winardi. 2002. Pengantar Ilmu Ekonomi. Cetakan Ketujuh. Bandung: Tarsito

Yunita Ima, 2013. Analisis Kelayakan Usaha Dodol Pulut Di Desa Paloh Kecamatan Peusangan Kabupaten Bireuen. Fakultas Pertanian Universitas Almuslim. Jurnal S. Pertanian, 1 (10): 826- 836. 